\title{
451 電力貯蔵磁気軸受フライホイール搭載電気自動車の研究
}

\section{Energy Storage AMB Flywheel Powered Electric Vehicle}

\author{
佛慈 浪漫人, 野波 健蔵, 島崎 浩, 鏡石 岳弘, Gede Indrawan \\ 千葉大学大学院工学研究科
}

\begin{abstract}
Budi Rachmanto, Kenzo Nonami, Shimazaki Hiroshi, Kagamiishi Takehiro, Gede Indrawan Graduate School of Engineering, Chiba Univ., Japan
\end{abstract}

\begin{abstract}
This paper describes a novel concept and configuration of Electric Vehicle powered by flywheel with Active Magnetic Bearing suspended by gimbal mechanism to the vehicle body. The entire system consists of AMB Flywheel Energy Storage including energy charger/discharger module, mechanical 2-DOF gimbal, steer-by-wire module, and autonomous driving module as the supervising controller. This paper shows the results of outdoor field experiments including the efficiency measurement of the energy conversion system.
\end{abstract}

Key Words : Homopolar active magnetic bearing, Flywheel energy storage system, Electric vehicle, Steer-by-wire driving system, Regenerative braking

\section{A1. あ ら ま し}

本研究グループでは充電・放電の応答性やエネルギーの 長期的貯蔵性に優れた磁気軸受フライホイールの利点を 活かした磁気軸受フライホイール搭載型電気自動車とい うコンセプトのハイブリッド電気自動車を提案している.

\section{A2. エネルギー貯蔵フライホイール}

現在, 石油などに代表されるエネルギ一資源の埋蔵量に は限度があり,いずれはこれらのエネルギ一資源の枯渴が 心配されている.一方, エネルギー消費量は年々確実に伸 びており,こうしたことを背景に新たなエネルギ一資源の 開発やエネルギーの有効利用法を確立することが重要で ある. その中でエネルギ一の有効利用法の一つとして電力 貯蔵型磁気軸受フライホイールがある.

フライホイールは円盤に回転軸を取り付けたもので回 転軸を回転させることで電力を回転 (力学的) エネルギー として貯蔵する力学的なバッテリーである. 従来の蓄電池 に比べ充電に要する時間が短く, 充電・放電の応答にも優 れており高効率のエネルギー変換効率が期待されている.

また, 蓄電池のように鉛などの有害物質を使わないため 環境に優しい電池としても注目されている.さらに磁気軸 受フライホイールは軸受部分に設置された電磁石を制御 することで回転軸を非接触に支持することができるため, 摩擦によるエネルギ一損失が極めて少なくエネルギーの 長期的貯蔵が可能となる.

\section{A3. フライホイール搭載電気自動車}

電気自動車の回生ブレーキによって得られたエネルギー をフライホイールに貯蔵して再利用することで電気自動 車のエネルギ一効率の向上が期待される. 本論文では, 電

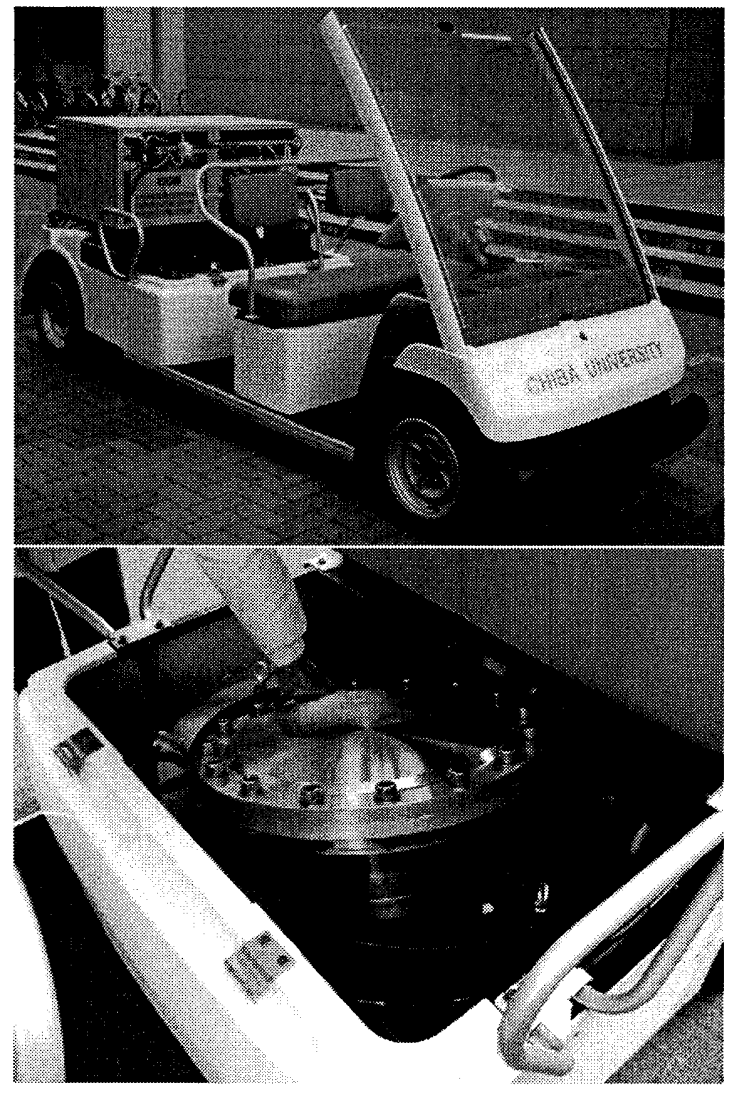

Fig. A1 Overview of AMB Flywheel Powered EV

力貯蔵磁気軸受フライホイールを搭載した電気自動車に おいて, 回生ブレーキにおけるエネルギー変換を重点に, システムの効率を検証し実験結果を報告する.

日本機械学会〔No.09-23〕 Dynamics and Design Conference 2009 CD-ROM 論文集〔2009.8.3-8,札幌〕 


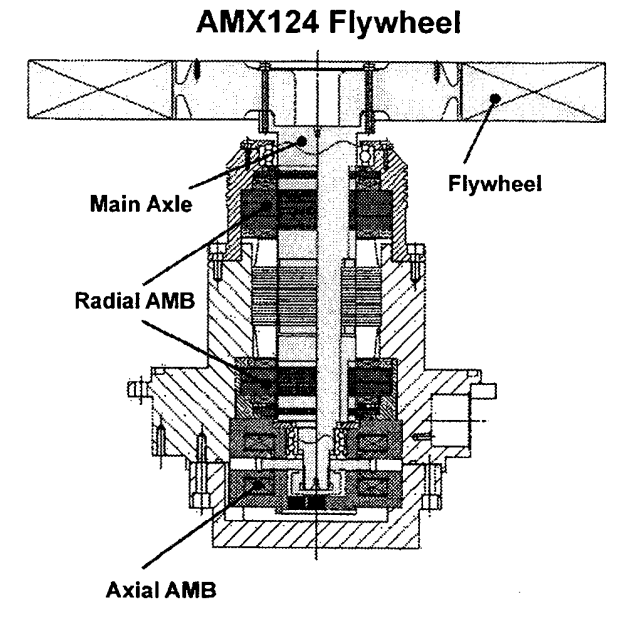

Fig. 1 Flywheel Energy Storage System with Active Magnetic Bearing

\section{1. 緒言}

エネルギー貯蔵フライホイール (FESS) は, 円盤を高速 回転させることでエネルギーを蓄え, 減速させることでエ ネルギーを放出する. システムは真空コンテナに入れた, ベアリングによって支持された回転体と電気モータ・ジェ ネレータからなっている.

アクティブ磁気軸受 (AMB) は, エネルギー効率を改善 するのに必要である. 従来の機械式ベアリングでは, 速度 に比例した摩擦でエネルギーのロスが増す。このことか ら, 本研究グループでは摩擦のない非接触型で高速回転可 能という利点で FESS にAMB を用いることにした.

通常, 磁気軸受は地面に固定した環境で使われるが,こ こではエネルギー貯蔵システムとして磁気軸受とジンバ ル機構で支持したフライホイールを搭載した車両を開発 した.

フライホイール付自動車 (殆どが機械式) は, 長い間開 発され,フライホイールシステムがより小さく,より軽く, より安く,より大きな能力を持つように研究がなされてき た. 提案したシステムは「低電力密度, 長充電時間, 高重 量, 環境に優しくない」という既存鉛バッテリシステムの 久点を取り除く.ただし, 磁気軸受のような摩擦のないべ アリングがなければ電池に比べ長時間エネルギーを保つ ことは難しく, また, 超高速回転のため安全性を十分確保 する必要がある.

\section{2. システム構成}

$2 \cdot 1$ プラットホーム本研究の電気自動車と磁気軸 受フライホイールの概観を図 A1 に示す. 電気自動車はヤ マハ発動機株式会社製のゴルフカート (TurfJoyG31E) を使 用している. 改造前の仕様は全長 $3560 \mathrm{~mm}$, 全幅 $1240 \mathrm{~mm}$, 全高 $1860 \mathrm{~mm}$, 乾燥質量 $360 \mathrm{~kg}$, 乗車人員 5 名, 最大積載量 $50 \mathrm{~kg}$ であり, フライホイールやジンバル機構, 制御装置を
Table 1 Parameters of AMB Flywheel System

\begin{tabular}{|l|lr|}
\hline \hline PARAMETER & \multicolumn{2}{|l|}{ VALUE } \\
\hline \hline Mass of main rotor shaft $\left(M_{r}\right)$ & 4.85 & $\mathrm{~kg}$ \\
\hline Mass of flywheel $\left(M_{f}\right)$ & 8.82 & $\mathrm{~kg}$ \\
\hline $\begin{array}{l}\text { Moment of inertia about } \\
z \text { axis }\left(I_{z}\right)\end{array}$ & $1.86 \times 10^{-1} \quad \mathrm{kgm}^{2}$ \\
\hline $\begin{array}{l}\text { Moment of inertia about } \\
x \text { and } y \text { axis }\left(I_{r}\right)\end{array}$ & $1.73 \times 10^{-1} \quad \mathrm{kgm}^{2}$ \\
\hline $\begin{array}{l}\text { Upper electromagnetic } \\
\text { constant }\left(K_{u}\right)\end{array}$ & $3.10 \times 10^{-6} \mathrm{Nm}^{2} / \mathrm{A}^{2}$ \\
\hline $\begin{array}{l}\text { Lower electromagnetic } \\
\text { constant }\left(K_{l}\right)\end{array}$ & $4.47 \times 10^{-6} \mathrm{Nm}^{2} / \mathrm{A}^{2}$ \\
\hline $\begin{array}{l}\text { Distance of upper radial AMB } \\
\text { to center of gravity }\left(L_{u}\right)\end{array}$ & $4.99 \times 10^{-2} \mathrm{~m}$ \\
\hline $\begin{array}{l}\text { Distance of lower radial AMB } \\
\text { to center of gravity }\left(L_{l}\right)\end{array}$ & $1.67 \times 10^{-1} \mathrm{~m}$ \\
\hline Rotor-AMB gap $\left(X_{0}\right),\left(Y_{0}\right)$ & $0.125 \times 10^{-3} \quad \mathrm{~m}$ \\
\hline \hline
\end{tabular}

十分搭載することが可能である. 座席下に 6 個, 計 $186 \mathrm{~kg}$ の鉛蓄電池が配置されている.

磁気軸受フライホイールにはロータ周りに半径方向 (ラ ジアル方向)に向かいあう2 対の電磁石が Upper 側 と Lower 側に直角になるように取り付けてある.さ らに回転軸方向 (アキシャル方向) に対しても向かい合う 2対の電磁石が取り付けてある. 磁気軸受フライホイール の位置制御は Upper 側と Lower 側の $\mathrm{x}, \mathrm{y}$ 方 向に 1つづつ位置センサが取り付けられており,これから ロータの位置を計測し,電磁石の吸引力を制御することで 行われる.この磁気軸受フライホイールは車両の後部座席 に設置したジンバル機構に取り付けてある.

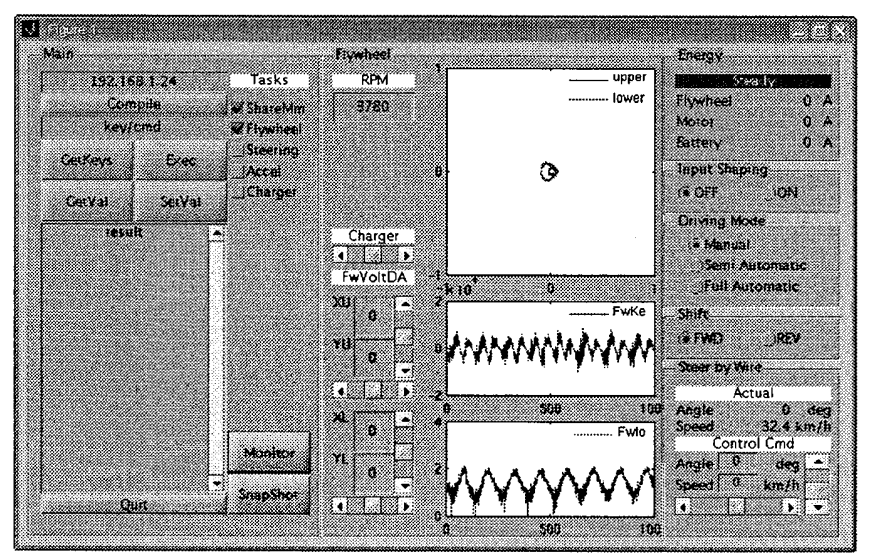

Fig. 2 Control panel

$2 \cdot 2$ 制御システム 図 2 は制御パネルを示している. フライホイールの回転速度や上軸, 下軸の軌跡, 充電・放電 の状態, 車輪の角度, 速度などが表示され，それぞれが制御 できる. プログラムは全て C で作成している. MATLAB ${ }^{\circledR}$ は GUI とデータ解析でのみ利用される.

制御システムの頭脳となるコンパクト $\mathrm{PCI}(\mathrm{cPCI})$ ベー スの主コンピュータにはフライホイール安定化制御, ステ アリング・アクセル制御, 電力制御, 自律運転制御, 及び経 路探索制御モジュールが組み込まれている. フライホイー 


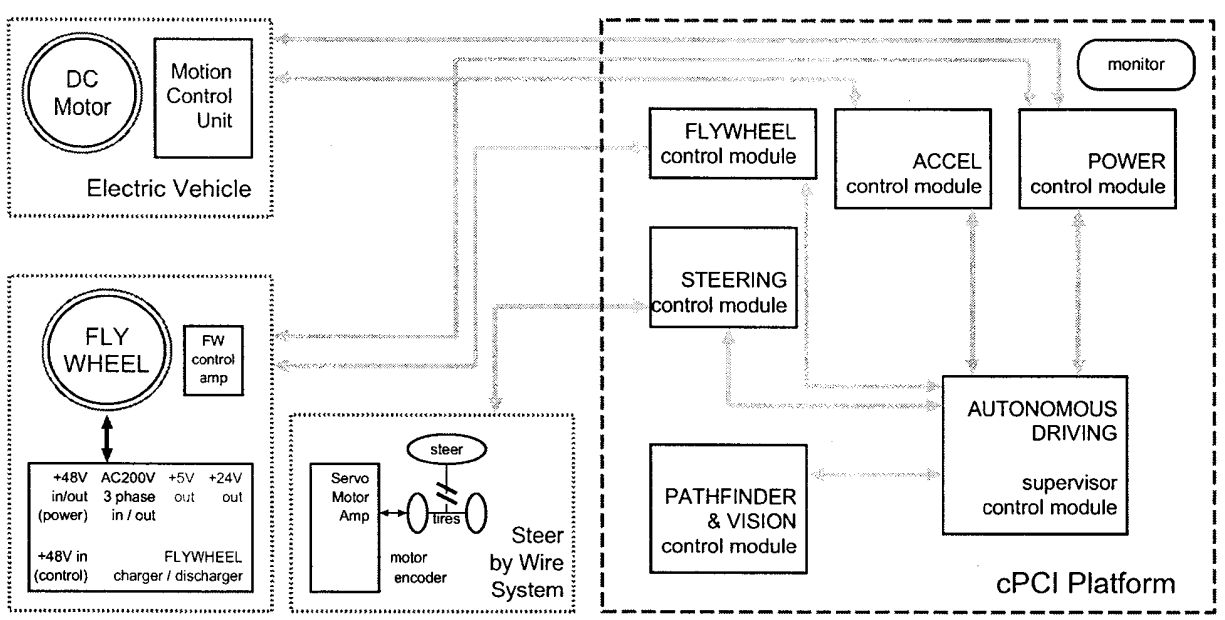

Fig. 3 Overview of the whole control system

ルの充電・放電モードは主コンピュータによって制御で き,アクセルペダルからの信号で切り替わる.これら制御 システム全体の概略を表しているのは図 3 である。

EV は完全自律, または半自律運転モードで走行できる. 良い操作性を保つにはこの概念は重要である.ドライバか らの加減速・旋回指令は一旦 cPCI コンピュータに送られ 振動やジャイロ効果の軽減のために再計算され, やがては ステアリング・アクセルコントローラに送信される.
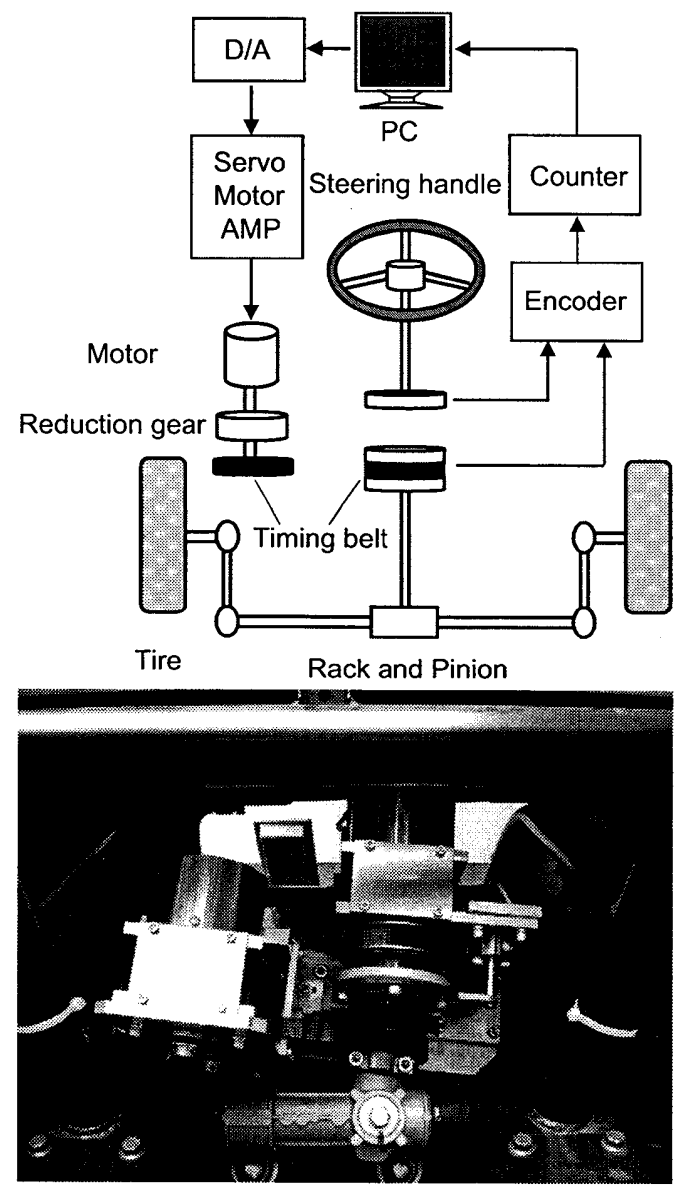

Fig. 4 Steer-by-Wire system
2.3 Steer-by-Wire 操舵システム SBW (Steer By Wire) システムとはステアリングギヤとステアリングコラ ムを機械的に切り離し,電気信号による情報送受によりス テアリングの操舵を行う EPS(Electric Power Steering) シ ステムである. ハンドルとの干渉がないため自在な制御 が可能となる. SBW-EPS システムの構成図を図 4 に示す. SBW-EPS システムは, ハンドル角とステアリング角を検 出するエンコーダとカウンタ, ステアリングギヤを駆動す るモータとモータ制御ドライバ, 制御演算を行う PC, モー タ制御ドライバに演算結果 (指令トルク)を与える D/A 変 換器で構成される. また, モータトルクを増幅するために 減速ギヤが取り付けてある. ハンドルとステアリングに取 り付けたエンコーダによりカウンタによってハンドル角 とステアリング角を取得を行い, PC で制御演算を行った 後 D/A 変換器を通してモータ制御ドライバに指令トルク を与えることによってモータの制御は行われる.

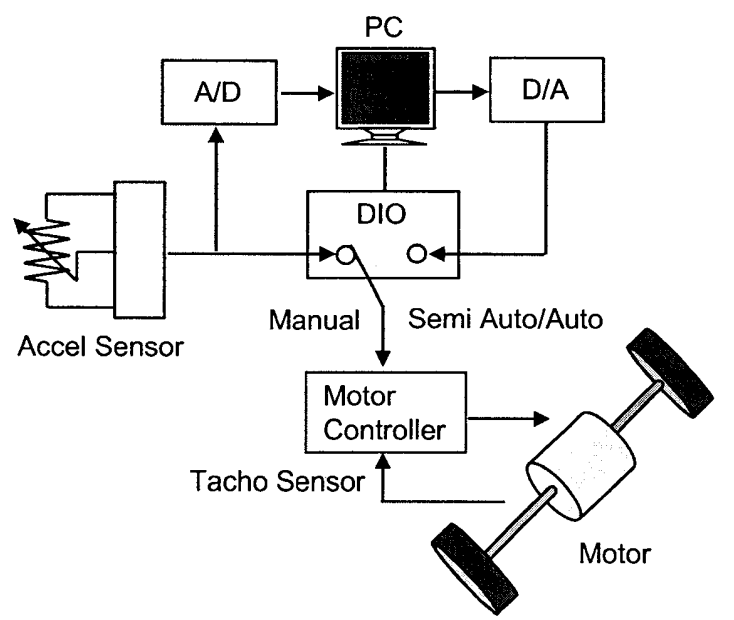

Fig. 5 Configuration of accel control in manual or semi/full autonomous driving system

2.4 アクセル操作システムアクセル操作システム の構成を図 5 に示す.アクセル操作システムは操縦者のア 
クセル操作量を検出するアクセルセンサ (ポテンショメー タ), アクセルセンサの信号を PC に取得するための A/D 変換器, 制御演算を行う PC, モ一夕制御器に車両の速度目 標值を与える D/A 変換器で構成されている. マニュアル 運転と半自律運転の切り替えはメカニカルリレー (DIO) によって行われる. 半自律運転システムでは, アクセルセ ンサの信号をいったん PC に取り込み制御演算を行った 後, 演算された速度目標值をモータ制御器に指令すること によってフライホイールのタッチダウンを抑制するアク セル操作のアシストが行われる.

2.5 フライホイールエネルギー変換システムフラ イホイールと EV との間のエネルギー変換は充放電器を 介して行われる. EV のシステム電圧は DC 48V であるが, フライホイールのモータ・ジェネレータは 3 相 AC $200 \mathrm{~V}$ の誘導型となっている. フライホイールを充電するときは EV からの電流をチョツパで昇圧し交流に変換し誘導モー タとのスリップ率を正に上げてフライホイールを回転さ せる.

逆に, フライホイールからエネルギーを取り出す場合は, 誘導モータとのスリップ率を負に下げ, 得られた電流を整 流器や降圧チョッパを用いて EV のシステム電圧に変換し て放電する.

\section{3. 実験}

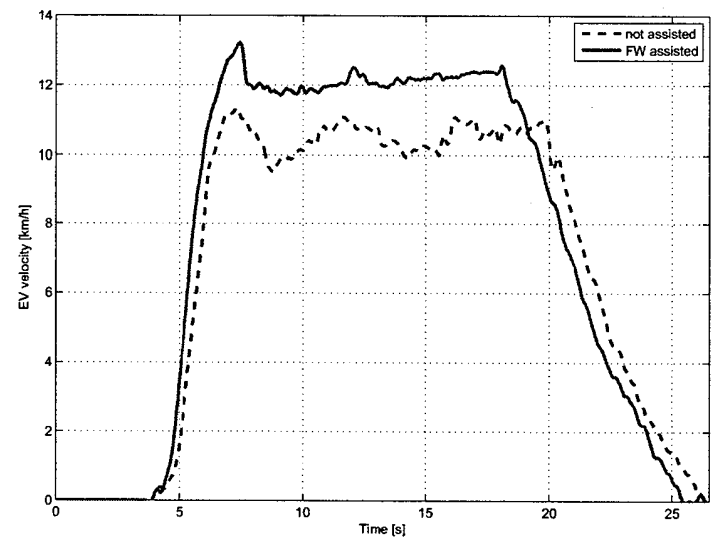

Fig. 6 Comparison of EV velocities with/without flywheel energy

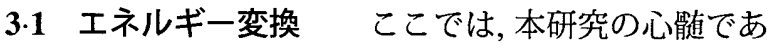
る,エネルギー変換について述べる. 上記に示したように, 化学電池の代替品としてフライホイールをエネルギー貯 蔵タンクとして利用する自動車の実現を目指している.

図 6 はフライホイールシステムを有効 (または無効)に した時の EV の速度を表している. 有効にした場合, フラ イホイールが加速を促進する. 無効のときに比べて, EV のパワーが 20\%-50\% 程向上した.

図 7 はフライホイールシステムを有効 (または無効) に

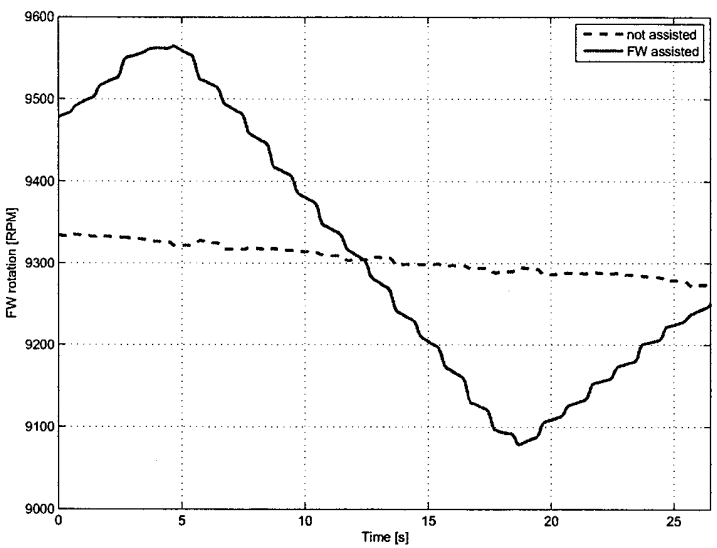

Fig. 7 Comparison of flywheel rotations when FESS is activated/deactivated

した時のフライホイールの回転速度を表している.アイド リング時, フライホイールは充電され, EV が動き出すと 充放電器はフライホイールからのエネルギーを取り出し, EV が減速したら再び充電が行われる.

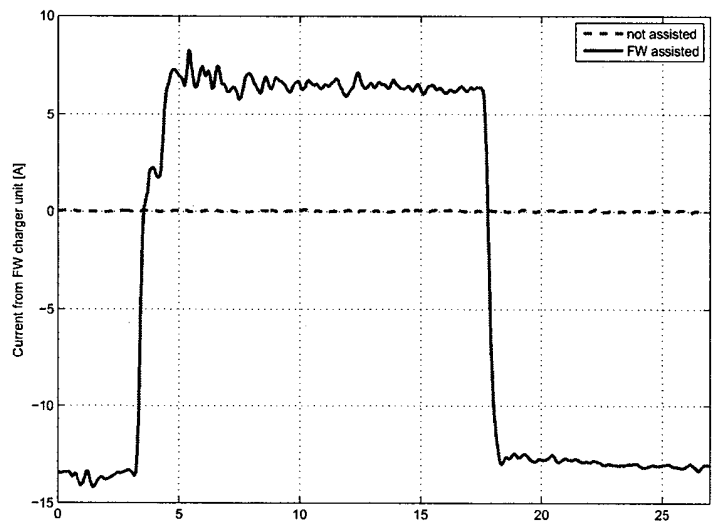

Fig. 8 Comparison of charger/discharger unit currents when FESS is activated/deactivated

図 8 は充放電器からの電流を表している. 負の值はフ ライホイールに流れる電流を, 正の值は放電つまり, フラ イホイールから流れ出すエネルギーを表している. 図に示 したように, 充電・放電の際に流れる電流はほぼ一定であ る.これは, 現在のフライホイールシステムではフライホ イールの回転速度や流せる電流に制限があるためで, 将来 フライホイールの容量等を増やしこれらの制限を解除す る予定である.

図 9 から DC モータに流れる電流はわかる. 負の值は 入ってくる電流を, 正の值はモ一タから流れ出す電流を表 している. また, 眓から EV が減速した時に回生電流が発 生していることが見て取れる.

図 10 は鉛蓄電池からの電流を示している. EV が走行 


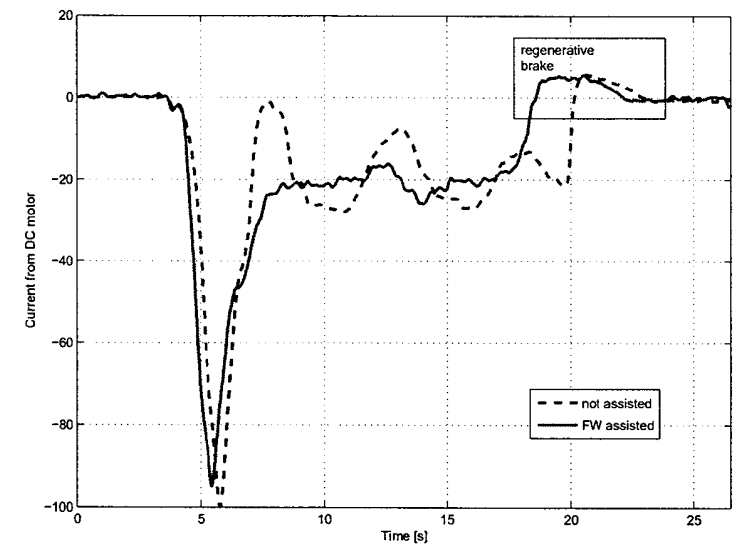

Fig. 9 Comparison of motor currents when FESS is activated/deactivated

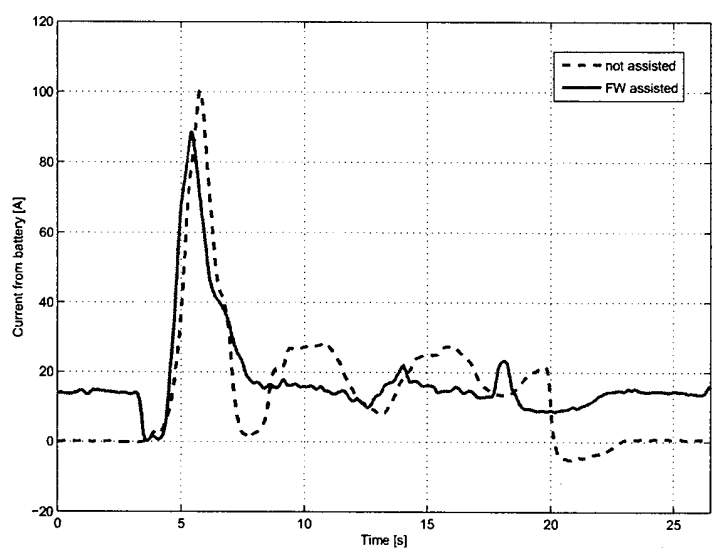

Fig. 10 Comparison of battery currents when FESS is activated/deactivated

中でフライホイール補助が有効な場合, DC モータは電池 からのエネルギーの使用を軽減できる. この時, DC モータ は充放電器がフライホイールから取り出したエネルギー を利用することになる.

図 11 と図 12 は,フライホイールシステムが有効(また は無効)にしたときの, EV に流れる充放電器, モ一タ, 及 び鉛蓄電池からの電流の関係を示している. 図 9, 図 11 及 び図 12 に示すように DC モータはジェネレータとして回 生電流を出す能力を持っているが純正のモータではその 回生時間がせいぜい 5 秒と短く流れる電流もごくわずか である.

3.2 回生ブレーキ 別の実験結果ではあるが, 回生 電流が発生したときのグラフを拡大すると図 13 となる. ここでは,EV が減速する際に発生する回生電流はおよそ 5.5 秒間続いている.

回生ブレーキ時はフライホイール充放電器は即座に充 電モードに切り替わり EV (DC モータや鉛蓄電池)に対し

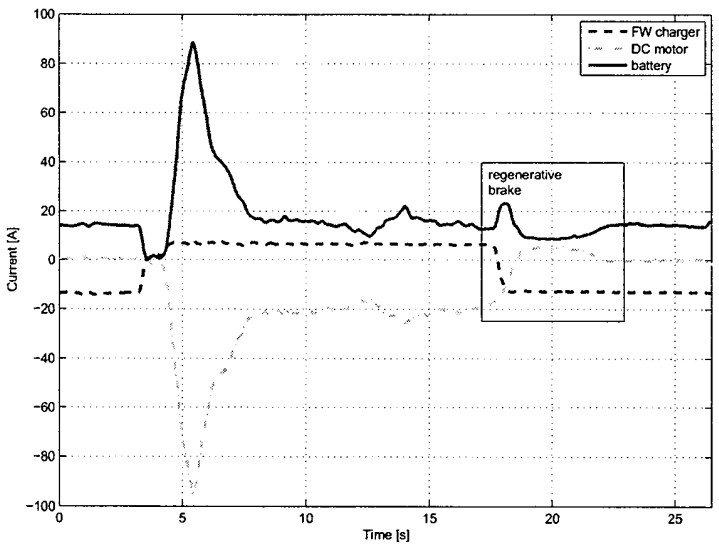

Fig. 11 Currents flowing in the system (FESS activated)

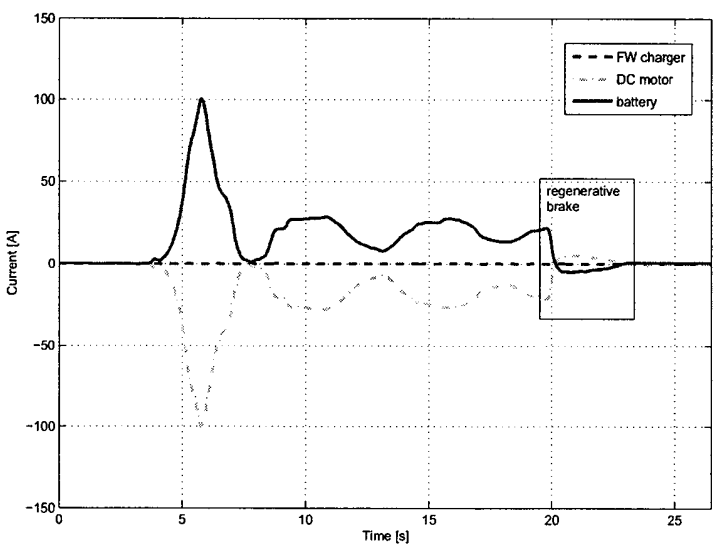

Fig. 12 Currents flowing in the system (FESS deactivated)

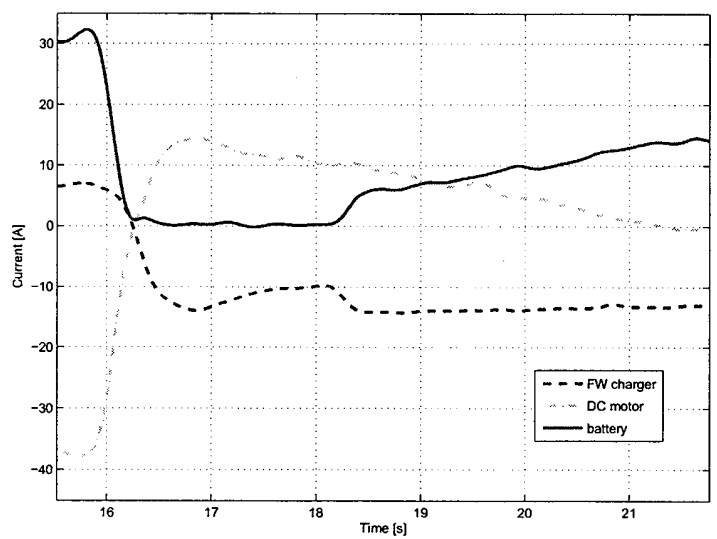

Fig. 13 Currents flowing on regenerative braking

て電流を要求するが, この実験では最初の 2 秒間は鉛蓄電 池からの電流は発生しておらず, ジェネレータモードに切 り替わった EV の DC モータから流れ出た回生電流はそ のままフライホイール充放電器に流れ込むことが見て取 れる. 
2 秒後はようやく鉛蓄電池が反応してフライホイール 充放電器が要求する電流の不足分を補っていく. 回生電流 が終わるとフライホイールへの充電は今度, 鉛蓄電池で賄 われることになる.

\section{4. 結言と今後の予定}

磁気軸受フライホイール搭載型電気自動車 (AMBFPEV) というコンセプトの電気自動車を提案した. EV のシステム構成を示し, 電動操舵 (steer-by-wire) システム 及び AMB フライホイールシステムを述べた. 特にエネル ギ一変換システムについて,フライホイール付電気自動車 が有用であることは実走行での実験結果からも示した.

図 6 より,EV の加速に FESS が効果的であることは見 て取れる.一方, エネルギーを有効活用するために, より 効率の良いモータ・ジェネレータを使わなければならな い. 現在, 充放電システムをはじめ, システム全体の効率 向上のために最適化を行っている.

\section{文献}

(1) Kenzo Nonami, et.al.: AMB Flywheel-Powered Electric Vehicle, The 11th International Symposium on Magnetic Bearings, Nara, Japan, August 26-29, 2008.

(2) Hayes, R,J., Kajs, J.P., Thompson, R.C, Beno, J.H.: Design and Testing of a Flywheel Battery for a Transit Bus, SAE 1999-01-1159.

(3) Kenta Kuriyama, Kenzo Nonami and Budi Rachmanto; Attitude Stabilization Control of AMB-Flywheel Supported by Two-Axes Gimbals, The 11th International Symposium on Magnetic Bearings, Nara, Japan, August 26-29, 2008.

(4) Budi Rachmanto and Kenzo Nonami; Zero Bias MIMO Simple Adaptive Control on Low-Loss Homopolar Flywheel with Active Magnetic Bearings, Dynamics and Design Conference, The Japan Society of Mechanical Engineers, Hiyoshi, Kanagawa, Japan, Sept. 2, 2008.

(5) Budi Rachmanto, Kenzo Nonami and Kenta Kuriyama; Attitude Control of Flywheel with Two-Axis Gimbal and Nonlinear Input Shaping, The 11th International Symposium on Magnetic Bearings, Nara, Japan, August 26-29, 2008. 